\title{
1
}

\section{Biogeochemistry of Nickel and Its Release into the Environment}

\author{
Tiina M. Nieminen, ${ }^{1}$ Liisa Ukonmaanaho, ${ }^{1}$ Nicole Rausch, ${ }^{2}$ and \\ William Shotyk ${ }^{2}$ \\ ${ }^{1}$ Finnish Forest Research Institute (Metla), \\ FI-01301 Vantaa, Finland \\ $<$ tiina.nieminen@metla.fi> \\ $<$ liisa.ukonmaanaho@metla.fi> \\ ${ }^{2}$ Institute of Environmental Geochemistry, University of Heidelberg, \\ D-69120 Heidelberg, Germany \\ $<$ nicole.rausch@ec.europa.eu> \\ $<$ shotyk@ugc.uni-heidelberg.de>
}

1. INTRODUCTION 2

2. CHEMISTRY OF NICKEL

2.1. Chemical Properties 2

2.2. Geological Abundance and Occurrence 4

2.3. Measurement of Nickel in Environmental Samples 4

3. ANCIENT AND MODERN USES OF NICKEL 6

4. SOURCES OF ATMOSPHERIC NICKEL 6

4.1. Natural Sources 6

4.2. Anthropogenic Sources 7

5. DEPOSITION AND FATE OF ATMOSPHERIC NICKEL 7

5.1. Air Quality and Deposition in Polluted Areas

versus Remote Areas $\quad 7$

5.2. Regional Indicator Surveys: The Use of Mosses, Lichens, Bark 8

5.2.1. Mosses 8

5.2.2. Lichens 9

$\begin{array}{ll}\text { 5.2.3. Bark } & 10\end{array}$

Metal Ions in Life Sciences, Volume 2 Edited by Astrid Sigel, Helmut Sigel and Roland K. O. Sigel

(C) 2007 John Wiley \& Sons, Ltd 
5.3. Nickel Concentration in Aquatic and Biotic Media 10

5.4. Nickel Fluxes in Forested Catchments 12

6. HISTORICAL RECORDS OF NICKEL DEPOSITION 14

6.1. Sediment 14

6.2. Peat Bog 15

6.3. Polar Snow and Ice 15

7. BIOAVAILABILITY AND MOBILITY OF NICKEL IN SOILS 17

7.1. Uptake and Translocation of Nickel by Plants 17

7.2. Importance of Partitioning for Bioavailability and Mobility $\quad 19$

8. SUMMARY AND CONCLUSIONS 21

ABBREVIATIONS 21

REFERENCES $\quad 22$

\section{INTRODUCTION}

Nickel and its compounds are released into the atmosphere from both natural and anthropogenic sources. Although $\mathrm{Ni}$ is an essential element to plants and many other biota, there has been much more concern about the toxicity of Ni than about $\mathrm{Ni}$ deficiency. Field observations have indicated a significant increase in heavy metal concentrations in agricultural and forest soils as well as in marine and inland water sediments during the last century [1,2]. An increase is also frequently observed in remote areas thousands of kilometers away from major anthropogenic sources due to long-range atmospheric transport, e.g., elevated Ni concentrations have been reported from the Norwegian arctic and the Finnish Lapland region [3-5]. Nriagu and Pacyna [6] give an estimation of 24000-87000 tons in 1983 for the worldwide Ni emissions to the atmosphere, and for the total global release of $\mathrm{Ni}$ into soils (atmospheric fallout, wastes, fertilizers, sewage sludge, etc.) an estimate ranging from 106000 to 544000 tons per year. In this context, it is important to know the background concentrations of trace elements in uncontaminated sites for comparison with polluted areas.

\section{CHEMISTRY OF NICKEL}

\subsection{Chemical Properties}

Nickel ( $Z=28$, atomic weight 58.69) belongs to Group 10 (formerly VIII) of the periodic table, the so-called iron-cobalt-nickel group of metals. As such, 


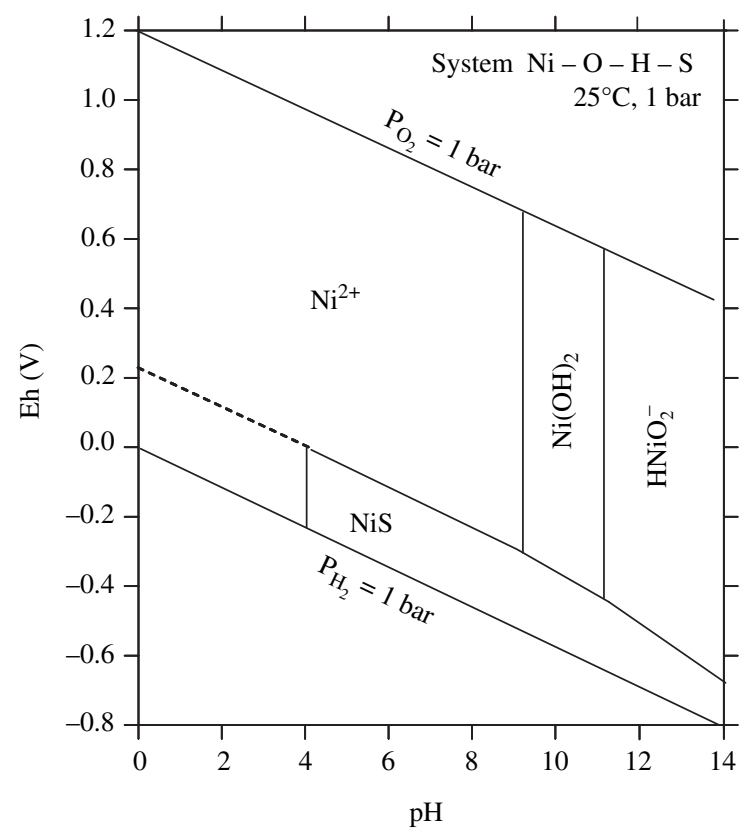

Figure 1. Eh-pH diagram for part of the system Ni-O-H-S. Assumed activities for dissolved species are $\left[\mathrm{Ni}^{2+}\right]=10^{-6},\left[\mathrm{~S}^{2-}\right]=10^{-3}$. Redrawn from [9] with kind permission of Springer Science and Business Media.

$\mathrm{Ni}$ is closely related to Co in both its chemical and biochemical properties. The electronic configuration is (Ar) $3 d^{8} 4 s^{2}$. Normally, Ni occurs either in the 0 or + II oxidation states, although the + I and + III states can exist under certain conditions. As the latter ions are not stable in aqueous solution [7], redox processes are not directly important in the environment. Elemental $\mathrm{Ni}$ is a silvery white, hard, malleable metal which melts at $1453^{\circ} \mathrm{C}$ and has a density of $8.9 \mathrm{~g} \mathrm{~cm}^{-1}$. Five stable isotopes exist of $\mathrm{Ni}$ (with natural abundances): ${ }^{58} \mathrm{Ni}(67.9 \%),{ }^{60} \mathrm{Ni}(26.2 \%)$, ${ }^{61} \mathrm{Ni}(1.19 \%),{ }^{62} \mathrm{Ni}(3.66 \%)$, and ${ }^{64} \mathrm{Ni}(1.08 \%)$. There are 18 radioisotopes, with the most stable being ${ }^{59} \mathrm{Ni}$ (half-life $76000 \mathrm{yr}$ ) and ${ }^{63} \mathrm{Ni}$ (half-life $100 \mathrm{yr}$ ). Nickel readily loses two electrons, yielding $\mathrm{Ni}^{2+}$. This is the dominant inorganic species throughout the $\mathrm{pH}$ and Eh range of most natural waters (Figure 1). However, in the presence of dissolved organic matter, $\mathrm{Ni}$ can form strong complexes with organic ligands. In increasingly calcareous/alkaline waters it is stable as $\mathrm{NiHCO}_{3}^{+}$ and $\mathrm{NiCO}_{3}^{0}$, and $\mathrm{Ni}(\mathrm{OH})_{2}^{0}$, respectively. In zones of active bacterial sulfate reduction such as anoxic sediments, the solubility of $\mathrm{Ni}$ is regulated by the formation of $\mathrm{Ni}$ sulfide $(\mathrm{NiS})$. In the presence of phosphate, as in fertilized agricultural soils, $\mathrm{Ni}_{3}\left(\mathrm{PO}_{4}\right)_{2}$ can be formed resulting in very low $\mathrm{Ni}^{2+}$ concentrations in the aqueous phase (solubility product about $10^{-32}$ ). In most soils, $\mathrm{Ni}$ is bound to ion 
exchange sites, is specifically adsorbed, or adsorbed on or coprecipitated with aluminum and iron oxyhydroxides. These are the dominant processes in neutral to alkaline soils. In acidic organic-rich soils, where fulvic and humic acids are formed by the decomposition of organic material, Ni may be quite mobile, possibly because of complexation by these ligands [8].

\subsection{Geological Abundance and Occurrence}

The abundance of Ni in the earth's crust is $\sim 80 \mu \mathrm{gg}^{-1}$ [7]. While concentrations in most rocks are below $150 \mu \mathrm{g} \mathrm{g}^{-1}$ (sedimentary rocks: $\leqslant 70 \mu \mathrm{g} \mathrm{g}^{-1}$; basalts: $150 \mu \mathrm{g} \mathrm{g}^{-1}$, granitic rocks: $\leqslant 15 \mu \mathrm{g} \mathrm{g}^{-1}$ ), $\mathrm{Ni}$ is highly enriched in ultramafic rocks such as peridotite and serpentine $\left(2000 \mu \mathrm{g} \mathrm{g}^{-1}\right)$ [10], as well as meteorites (5-20\% $\mathrm{Ni}$ ). Nickel as a chalcophilic element forms many different sulfides, arsenides as well as antimonides in nature (e.g., NiS, NiAs, $\mathrm{NiAs}_{2-3}$, NiAsS, NiSb, NiSbS). There exist two different types of commercially exploitable deposits: sulfide ores, with pyrrhotite, pentlandite, pyrite and chalcopyrite as the main Ni-containing minerals, and laterites, formed during tropic weathering, such as garnierite $\left((\mathrm{Mg}, \mathrm{Ni})_{3}(\mathrm{OH})_{4}\left[\mathrm{Si}_{2} \mathrm{O}_{5}\right]\right)$. The latter can often be mined in open pits. The main $\mathrm{Ni}$ producers are Canada (sulfidic ores at the Sudbury and Thompson mines), Russia (laterites and pentlandite at Norilsk and Pechenga), and Indonesia and Australia (laterites).

\subsection{Measurement of Nickel in Environmental Samples}

The concentrations of total $\mathrm{Ni}$ in uncontaminated environmental samples range from $0.6 \mathrm{pg} \mathrm{g}^{-1}$ in ice-core samples [11] to more than $1 \mathrm{mg} \mathrm{g}^{-1}$ in serpentine soils [7]. The most common techniques for the quantification of $\mathrm{Ni}$ in these samples are atomic absorption spectrometry (AAS), inductively coupled plasma optical emission spectrometry (ICP-OES), and inductively coupled plasma-mass spectrometry (ICP-MS). Approved test methods are given by the Environmental Protection Agency (EPA) [12-14].

Limits of detection (LODs) of $40 \mu \mathrm{g} \mathrm{L}^{-1}$ are reported for the analysis of water samples using flame AAS, and $1 \mu \mathrm{gL}^{-1}$ using graphite furnace AAS [12,13]. A great advantage of ICP-OES and ICP-MS is their capability of multi-element analysis. An additional advantage of ICP-MS is the low LOD for most elements (lower $\mu \mathrm{g} \mathrm{L}{ }^{-1}$ range). Although these methods are suitable for acid digestions of soil and sediment samples as well as many water samples, the Ni concentration in some natural and drinking waters is often below the LODs of the ICP-MS. Therefore, the EPA specifically developed three different preconcentration protocols for the determination of metals in ambient waters at EPA water quality criteria levels (WQC), resulting in a LOD of $0.029 \mu \mathrm{g} \mathrm{L}^{-1}$ for Ni [14]. 
However, one of the greatest difficulties in measuring $\mathrm{Ni}$ at these levels is precluding sample contamination during collection, transport, and analysis. Over the past decades, marine chemists have come to recognize that much of the historical data on the concentrations of $\mathrm{Ni}$ in seawater are erroneously high because the concentrations reflect contamination from sampling and analysis rather than ambient levels [14]. Therefore, the EPA developed a clean sampling procedure of ambient water [14]. Solid phase extraction is a very sensitive, fast and economic preconcentration method [15], and various extractants are reported in the recent literature [15-24]. Alternatively, Ni can be preconcentrated using coprecipitation $[25,26]$. With the development of high-resolution ICP-MS instruments and the installation of clean lab facilities, a new chapter in Ni quantification has been opened. The main advantages compared with quadrupole ICP-MS instruments are: (1) increased sensitivity (factor 10); (2) low background intensities; (3) the separation of Ni from polyatomic interferences $(\mathrm{CaO}, \mathrm{CaOH})$; and (4) the small sample volumes required. This allowed the multi-element analysis of bog porewater [27] where preconcentration procedures were not possible due to the low sample amounts available. Due to the low background levels of the instrument, LODs are dependent on the effort to avoid random sample contamination. Using class 100 flow benches and high-purity materials (Teflon, Peek), e.g., LODs of $15 \mathrm{ng} \mathrm{L}^{-1}$ could be obtained for $\mathrm{Ni}$ [27].

Using the slurry-sample introduction technique in AAS [28,29] and laserablation ICP-MS [29], the direct determination of $\mathrm{Ni}$ in solid environmental samples, without time-consuming digestion procedures, is possible. The LODs attainable with laser-ablation ICP-MS depend on the size of the ablation pits, but are typically in the low to sub $\mathrm{ng} \mathrm{g}^{-1}$ range for pits of $>100 \mu \mathrm{m}$ [30]. However, XRF spectrometry is a cheap, fast and simple alternative for the multi-element analysis of solid samples at the $\mu \mathrm{gg}^{-1}$ concentration level, and it is non-destructive. Using total reflexion XRF, aqueous solutions can be analyzed [31,32]. For analyzing small samples, such as single mineral grains, electron microprobe analyzers (EMPA) have been used extensively, although LODs are in general high $\left(50-200 \mu \mathrm{g} \mathrm{g}^{-1}\right.$ for many elements) [33]. Synchrotron-based XRF allows the establishment of elemental mappings of small-scale samples, with lateral resolutions in the $\mu \mathrm{m}$ range [34]. By combining different synchrotron X-ray techniques, such as X-ray diffraction, $\mathrm{X}$-ray absorption fine-structure analysis (XAFS), and X-ray absorption near edge structure analysis (XANES), information on the mineral phase, the oxidation state and the nearest neighbour atom can be obtained [35-37].

For the speciation of $\mathrm{Ni}$ in aqueous solutions, adsorptive cathodic stripping voltammetry is frequently employed [38-40]. Using chromatographic methods both speciation and the separation of different metals in aqueous solutions is possible. A recent review covers standard separations of inorganic ions and metal complexes such as ion chromatography, as well as advanced techniques such as capillary electrophoresis (CE) [41]. The advantages of CE include the high separation speed $(<10 \mathrm{~min})$ and separation efficiency, and the small sample volumes 
required (several $\mathrm{nL}$ ). Metals can be detected either by nonspecific UV detection, or by using an element-specific ICP-MS coupled to the CE instrument.

\section{ANCIENT AND MODERN USES OF NICKEL}

The use of Ni can be traced back to the beginning of the Bronze Age in Mesopotamia in $3500 \mathrm{BC}$. The ancient bronzes produced in the area had a Ni content of up to $2 \%$. The naturally occurring nickel-copper alloys were used by the Chinese during their Bronze Age from ca 2000 BC. However, the real understanding of Ni as an element dates to more contemporary times. In 1751 the Swedish chemist and metallurgist, Cronstedt isolated a white metal, which he called nickel, from a mineral originating from the $\mathrm{Los} \mathrm{Cu}-\mathrm{Co}$ mines in Sweden. It is not quite evident what was the Ni containing mineral, from which Ni was identified by Cronstedt, but very probably it was 'kupfernickel' now called niccolite (NiAs). The name 'nickel' originates from the old name of this mineral. Although kupfernickel looked like a $\mathrm{Cu}$ mineral, one could not extract any $\mathrm{Cu}$ from it. Therefore the Saxon miners had named the mineral according to a spiteful dwarf 'Nickel' who had apparently turned the $\mathrm{Cu}$ in the ore into a non-available form.

Nickel is an important element in modern industry. The largest use by far is the manufacture of stainless steel, an alloy that consists of $8 \%$ nickel, $18 \%$ chromium and $74 \%$ iron. Other special steels can contain up to $60 \%$ of Ni. There are more than 3000 known Ni-containing alloys. Finely divided Ni is used as a catalyst for hydrogenating vegetable oils. Batteries contain $\mathrm{Ni}$, especially the advanced $\mathrm{Ni}-\mathrm{Cd}$ batteries of electric vehicles. Nickel can be electroplated onto other metals to form a protective coating on electronic components. Various Ni compounds are used as pigments [42].

\section{SOURCES OF ATMOSPHERIC NICKEL}

\subsection{Natural Sources}

There are large amounts of natural Ni present in the atmosphere, derived from windblown dust, volcanic ashes, forest fires, meteoric dust and sea salt spray. On a global scale, windblown soil particles from eroded areas can account for $30-50 \%$ of natural Ni emissions. Volcanoes eject material from the Earth's mantle and this source can also account for a significant portion, perhaps $40-50 \%$ of $\mathrm{Ni}$, in the air [1]. Nickel, which has been incorporated into vegetation can be released and dispersed by forest fires. Therefore, the natural background concentration in the air varies according to local sources and specific climatic conditions. Estimates from natural emissions are still rather inaccurate. Pacyna and Pacyna [2] estimate that the natural emissions would be roughly one-third 
(30000 tons) of the anthropogenic emissions. However, locally the ratio of natural to anthropogenic emissions can be entirely different, e.g., in the neighborhood of volcanoes.

\subsection{Anthropogenic Sources}

Important sources of $\mathrm{Ni}$ are present and past mining activities, including foundries and smelters and refineries; diffuse sources such as piping, constituents of industrial and commercial products, combustion by-products, waste disposal, and traffic [43]. However, the main anthropogenic source of $\mathrm{Ni}$ is the combustion of oil, emitting 86110 tons of $\mathrm{Ni}$ in 1995 , which is more than twice as high as the corresponding emissions in 1983 (40833 tons) [2]. The increase can be explained by increased production of electricity and heat by oil combustion worldwide. Actually almost $90 \%$ of the global anthropogenic Ni emissions originate from oil combustion [2]. The worldwide emissions of Ni from non-ferrous metal production in 1995 was 8876 tons [2].

Historical records, derived from peat bog profiles or ice cores (see also Section 6), have shown that trace metal pollution started to increase at the beginning of the Second Industrial Revolution, between 1850 and 1900, when worldwide Ni emissions have been estimated to be close to 240 tons year $^{-1}$ [1]. Over a hundred

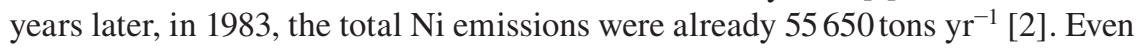
though the emissions of most metals have decreased since 1980s, global Ni emissions reached a level of 95287 tons $\mathrm{yr}^{-1}$ in 1995 , largely due to the increase in oil combustion. However, at a local scale trends can be different, e.g., in Finland Ni emissions declined by 50\% between the 1990 and 2000 [44]. The decline is supposed to result from the use of more efficient techniques and combustion processes together with better process control. Removal of Ni containing particles has also become more efficient owing to the installation of new sulfur removal systems [45]. The largest anthropogenic sources of atmospheric Ni emissions are estimated to be in Asia where emissions show an increasing trend, due to increasing industrialization and lower efficiency of emission control [2].

\section{DEPOSITION AND FATE OF ATMOSPHERIC NICKEL}

\subsection{Air Quality and Deposition in Polluted Areas versus Remote Areas}

Nickel is emitted into the atmosphere mainly in particulate matter dispersed by the wind and deposited by both dry and wet deposition. The deposition rate and the transport distance depend on the location, stack height, size of the particle, and meteorological conditions. Nickel from anthropogenic sources is mostly in 
the form of oxides and sulfates of rather small particle size (mass median diameter about $1 \mu \mathrm{m}$ ) of which some 15-90\% is soluble [43]. Windblown dusts may contain mineral species of $\mathrm{Ni}$, which are often in the form of sulfides. The type of ore will govern the form of $\mathrm{Ni}$ emitted to the atmosphere from an ore-crushing plant [46]. The major part of the particles deposit in the vicinity of the source, but smaller particles are transported over longer distances. This is especially true in winter when the particles can remain suspended in the air for long periods of time. In the Arctic, air measurements show that concentration of $\mathrm{Ni}$ is higher in winter than in summer by more than one order of magnitude [47].

The Ni concentrations in ambient air show considerable variation. In a remote area in the Canadian Arctic levels of $0.38-0.62 \mathrm{ng} \mathrm{m}^{-3}$ were recorded [48], whereas a value of $124 \mathrm{ng} \mathrm{m}^{-3}$ was measured in the vicinity of a Ni smelter [49]. At a background site in northern Finland, a level of about $0.58 \mathrm{ng} \mathrm{m}^{-3}$ as an annual average value, was recorded during 1996-1998 [50-52], while a background value in southwestern Finland was $1.14 \mathrm{ng} \mathrm{m}^{-3}$ [53]. In a polluted area in southwestern Finland, in the vicinity of a $\mathrm{Cu}-\mathrm{Ni}$ smelter, daily peak values as high as $44-230 \mathrm{ng} \mathrm{m}^{-3}$ have been observed [54]. Ranges from 9 to $60 \mathrm{ng} \mathrm{m}^{-3}$ have been reported for European cities [43], and from 110 to $180 \mathrm{ng} \mathrm{m}^{-3}$ for heavily industrialized areas [55]. Moreover, in remote areas near volcanoes values as high as $330 \mathrm{ng} \mathrm{m}^{-3}$, have been measured [56]. According to Nriagu [1] average concentrations of $\mathrm{Ni}$ in urban areas are $52 \mathrm{ng} \mathrm{m}^{-3}$, at rural sites $4.3 \mathrm{ng} \mathrm{m}^{-3}$, and at remote sites $0.8 \mathrm{ng} \mathrm{m}^{-3}$.

Deposition of heavy metals including Ni has been monitored systematically in Europe at background sites since the 1990s in the EMEP programme (http:// www.emep.int/index_facts.html). In 2001 the measured Ni deposition varied between 54.6 and $7732.7 \mu \mathrm{g} \mathrm{m}^{-2}$ [57]. The highest deposition was recorded in Svanvik, Norway, at a site located near the Russian border, and under the influence of the $\mathrm{Ni}-\mathrm{Cu}$ smelters in the Kola Peninsula. The lowest annual Ni deposition was recorded at Irafoss, Iceland. In another study in a polluted area near a $\mathrm{Cu}-\mathrm{Ni}$ smelter in southwestern Finland, the average annual Ni deposition during 1993-1998 was $64 \mathrm{mg} \mathrm{m}^{-2}$ at $0.5 \mathrm{~km}$ from the main stack [58].

\subsection{Regional Indicator Surveys: The Use of Mosses, Lichens, Bark}

\subsubsection{Mosses}

The use of mosses as biomonitors of atmospheric pollution on a regional scale were started in the late 1960s in Sweden [59,60] and were gradually adapted by other Nordic countries [61-63]. Mosses receive most of their nutrients directly from the atmosphere, although the interaction with local litter and soil should not be underestimated [64]. The general uptake efficiency of different trace elements by mosses decreases in the order $\mathrm{Pb}>\mathrm{Co}, \mathrm{Cr}>\mathrm{Cu}, \mathrm{Cd}, \mathrm{Mo} \mathrm{Ni}, \mathrm{V}>\mathrm{Zn}>\mathrm{As}$ 
[65]. The glittering feather moss (Hylocomium splendens (Hedw.) B.S.G.) and the red-stemmed feather moss (Pleurozium schreberi (Brid.) Mitt.) are the most common species used in regional surveys in Nordic countries [66-68], even though they are known to be sensitive to pollution and do not grow, e.g., in severely $\mathrm{Cu}-\mathrm{Ni}$ contaminated areas [69].

According to Rühling [70] Ni concentrations in mosses over large parts of northern Europe are generally less than $2 \mu \mathrm{g} \mathrm{g}^{-1}$. In Finland, the Ni concentrations of a moss survey, which has been carried out in five-year intervals since 1985, have varied between 0.46 and $79.7 \mu \mathrm{g} \mathrm{g}^{-1}$ [68]. The highest concentrations have occurred near point sources, such as a large $\mathrm{Cu}-\mathrm{Ni}$ smelter in southwestern Finland. Higher maximal concentrations have been found in the Barents region, which covers the northwestern part of Russia (the Kola Peninsula), and the northern parts of Finland and Norway, including both heavily polluted industrial sites (Nikel, Zapoljarnii and Monchegorsk), and some of Europe's most pristine wilderness areas. In the Barents area, Ni concentrations varied from 0.96 to $396 \mu \mathrm{g} \mathrm{g}^{-1}$ and the median concentration was $5.39 \mu \mathrm{gg}^{-1}$ [42]. Studies conducted near Ni$\mathrm{Cu}$ smelters of Sudbury (Ontario, Canada) and a Ni refinery in Port Colborne (Ontario, Canada) showed that up to $980-1500 \mu \mathrm{g} \mathrm{Ni} \mathrm{g}^{-1}$ could accumulate in transplanted mosses in 30-day exposure periods. Naturally growing mosses in Ontario have been reported to contain $1.3-81 \mu \mathrm{gg}^{-1} \mathrm{Ni}[71]$.

\subsubsection{Lichens}

Epiphytic lichens have been extensively used in monitoring as well. The use of lichens as bioindicators of air quality was discovered by the Finnish botanist Nylander in the 19th century, when he noticed that lichens occurred only in the most sheltered locations in the famous Jardins du Luxembourg in Paris [72]. The physiology of lichens makes them sensitive and also vulnerable to air pollutants, especially to high levels of sulfur dioxide $\left(\mathrm{SO}_{2}\right)$. Therefore, epiphytic lichens are the first to disappear from the immediate surroundings of pollutant sources [72-74]. However, since they obtain their nutrients directly from aerial deposition $[75,76]$, they are efficient in trapping atmospheric heavy metals in low or moderate pollution conditions $[71,77,78]$.

The epiphytic lichen Hypogymnia physodes (L.) Nyl. is widely distributed and fairly resistant to impurities in the air [79], therefore it has been used commonly in regional surveys of heavy metal deposition [80-82]. In a regional survey in Finland, the average Ni concentration of $H$. physodes was $2.5 \mu \mathrm{g} \mathrm{g}^{-1}$ [83]. In the Kola Peninsula (Russia) near Ni-Cu smelters, H. physodes lichens were transplanted for a 3-month period, at distances ranging from 6 to $150 \mathrm{~km}$ from the smelters [73]. The Ni concentration decreased in lichens with distance from the smelter, but at $6 \mathrm{~km}$ the Ni concentration was as high as $2780 \mu \mathrm{gg}^{-1}$ (at $12 \mathrm{~km} 610 \mu \mathrm{g} \mathrm{Ni} \mathrm{g}^{-1}$; at

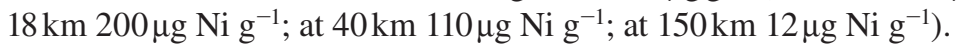


In a survey carried out with seven lichen species near the Sudbury smelters in Ontario (Canada) concentrations of $\mathrm{Ni}, \mathrm{Cu}, \mathrm{Fe}$, and $\mathrm{S}$ correlated with each other [84]. Concentrations of Ni ranged between 10 and $37 \mu \mathrm{gg}^{-1}$, Stereocaulon paschale (L.) Hofm. and Umbicularia spp. in particular accumulating larger quantities of Ni. In a more recent study by Case [85], carried out in the vicinity of the Sudbury smelters, the Ni concentration of Cladina species was on average $24 \mu \mathrm{g} \mathrm{g}^{-1}$ and at a background site ca $2 \mu \mathrm{g} \mathrm{Ni} \mathrm{g}^{-1}$. Backor and Fahselt [86] studied Cladonia pleurota (Flörke) Schaer. in a heavy-metal-rich site near a roasting bed as well as at a local background site in Sudbury. The average Ni concentration near the roasting bed was $212 \mu \mathrm{gg}^{-1}$ compared with the local background site $71.6 \mu \mathrm{gg}^{-1}$.

\subsubsection{Bark}

The use of tree bark as an indicator of air pollution increased in popularity after it was found that the $\mathrm{pH}$ of bark generally correlates well with atmospheric $\mathrm{SO}_{2}$ concentrations [87]. Results from the Kola Peninsula, Russia, and northern Finland indicated extremely high $\mathrm{Ni}$ concentrations in the bark of Scots pine (Pinus sylvestris L.) growing close to the $\mathrm{Ni}-\mathrm{Cu}$ smelters in Monchegorsk, with a maximum value of $303 \mu \mathrm{g} \mathrm{Ni} \mathrm{g}^{-1}$ [88]. The average Ni concentration of the Finnish study plots was only about $1 \mu \mathrm{gg}^{-1}$, and the range $0.05-6.64 \mu \mathrm{g} \mathrm{Ni} \mathrm{g}^{-1}$.

In a Canadian study, where bark samples were collected from a variety of tree species growing under varying contaminant loads, considerable variation among species was observed. Coniferous species (white spruce, black spruce, tamarack, white cedar, and jack pine) usually contained the highest concentrations of $\mathrm{Ni}$ ranging from 2 to $61 \mu \mathrm{g} \mathrm{Ni} \mathrm{g}{ }^{-1}$ [71], and the Ni concentrations of deciduous species varied from 1 to $37 \mu \mathrm{g} \mathrm{g}^{-1}$. In a Nigerian study carried out beside a road the $\mathrm{Ni}$ concentrations in bark of two tree species (Azadirachta indica A. Juss. and Gmelina arborea Linn. Roxb.) were on average $13 \mu \mathrm{gg}^{-1}$ [89].

\subsection{Nickel Concentration in Aquatic and Biotic Media}

Natural background levels of $\mathrm{Ni}$ in water are relatively low: in open ocean water $0.2-0.7 \mu \mathrm{gL}^{-1}$, and in fresh water systems generally less than $2 \mu \mathrm{gL}^{-1}$ [43]. In a Finnish study [90] median Ni concentrations in lakes were $0.38 \mu \mathrm{gL}^{-1}(n=153)$ and in stream waters $0.52 \mu \mathrm{g} \mathrm{L}^{-1}(n=1165)$. It is typical that heavy metal concentrations are lower in the headwater lakes than in streamwaters, possibly because of particle scavenging.

Nieminen et al. [91] compared Ni concentrations in the surface layers of a peat bog at a polluted site in the vicinity of $\mathrm{Cu}-\mathrm{Ni}$ smelters to that of a peat bog in a remote area. The Ni concentrations were 100 times higher near the smelter $\left(260-913 \mu \mathrm{g} \mathrm{g}^{-1}\right)$ compared with those of the remote site $\left(3-14 \mu \mathrm{g} \mathrm{g}^{-1}\right)$. Mannio 
et al. [92] studied enrichment of $\mathrm{Ni}$ in lake waters in Finland. They found out that an enrichment factor (EF) value of 2 was exceeded in only three lakes in Northeast Finland, near the Russian border, and the Kola Peninsula Ni-Cu smelters. These findings suggested that the current Ni concentration was more than twice the historical $\mathrm{Ni}$ concentration in those same lakes. Corresponding $\mathrm{Ni}$ EF values of lakes in northern Scandinavia have been reported to be less than $2[93,94]$.

Results of a study of various aqueous and biotic media in four remote sites in Finland indicate no bioaccumulation of Ni (Table 1), possibly a reflection of the generally low Ni concentration at all sites [95]. For example, the Ni concentrations of wood ant (Formica spp.) and the liver of shrew (Sorex spp.) were low compared with those found in moss, which should reflect the amount of atmospheric Ni deposition. Wood ant and shrew represent an important part of the ecosystem food chain. According to Tyler [96] the critical concentration value for $\mathrm{Ni}$ in mosses is $>20 \mu \mathrm{g} \mathrm{g}^{-1}$ and correspondingly in freshwater $25 \mu \mathrm{g} \mathrm{L}^{-1}$ [97]. Hence, the Ni concentration of both mosses and surface water in the remote Finnish sites was clearly below these ecotoxicological lowest effect values (Table 1).

Table 1. The range of median Ni concentration in aquatic and biotic media in 1-4 remote catchments in Finland (1989-1996). ${ }^{a}$

\begin{tabular}{lcc}
\hline & & $\mathrm{Ni}$ \\
\cline { 3 - 3 } Media & $n$ & Range between catchments \\
\hline Aquatic media & & $\left(\mu \mathrm{gL}^{-1}\right)$ \\
\hline Bulk precipitation & 308 & $0.31-0.5$ \\
Throughfall & 279 & $1.20-5.37$ \\
Stemflow & 61 & $7.99-10.90$ \\
Soil water & 61 & $8.63-11.89$ \\
Groundwater & 60 & $0.03-0.09$ \\
Lake water & 152 & $0.11-0.54$ \\
Streamwater & 101 & $0.16-0.46$ \\
\hline Biotic media & & $\mu \mathrm{gg}^{-1}$ dry matter \\
\hline Feather moss & 8 & $1.9-3.5$ \\
Humus layer & 72 & $5.7-8.4$ \\
Peat 0-80 cm & & 2.1 \\
Red wood ant & 16 & $0.4-0.5$ \\
Shrew (liver) & 53 & 0.1 \\
\hline
\end{tabular}

${ }^{a}$ Adapted and modified with permission from BER from Tables 3 and 4 in [95].

${ }^{b}$ Unpublished data from the Finnish Forest Research Institute. 
In a study conducted in an ultramafic (serpentine) soil, where a Ni hyperaccumulating plant (Alyssum pintodasilvae T. R. Dudley) was common, herbivores such as grasshoppers and predators such as spiders had significantly elevated concentrations of $\mathrm{Ni}$ [98]. In contrast, the concentrations of $\mathrm{Cr}$ and $\mathrm{Co}$, which are also enriched in ultramafic soils, but are not accumulated by A. pintodasilvaea, were not elevated in the studied invertebrates. Therefore, the presence of Ni hyperaccumulating plants appears to enhance the transfer of $\mathrm{Ni}$ from soil to herbivore and carnivore trophic levels. However, with the exception of hyperaccumulator plants, Ni does not biomagnify in the terrestrial foodweb [99], thereby its toxicity to higher trophic levels appears to be unlikely.

\subsection{Nickel Fluxes in Forested Catchments}

The atmospheric deposition of heavy metals is dominated by dry deposition of aerosols and particulates $[100,101]$. Forest canopies are particularly effective in trapping suspended heavy metal aerosols because of the high surface area for interception [102]. It is well known that the precipitation can wash many contaminants from the surfaces of vegetation. Less known is the fate of elements as the solution travels through the soil horizons and moves into streams. Some part of the elements absorbed by plants remain incorporated in stems, leaves, or moss tissues and are released back to the nutrient cycle only after senescence and litter decomposition. Input-output budgets at catchment and stand levels, therefore, are a useful means of describing the mobility, retention and fluxes of elements in the environment [103-108].

However, there are only a few elemental budgets published for Ni. Ukonmaanaho et al. [108] studied Ni input-output budgets both at plot (stand)- and catchmentscale in two remote boreal forest areas in southern (Valkea-Kotinen, Norway spruce dominated) and eastern (Hietajärvi, Scots pine dominated) Finland. Results of the plot-scale budgets showed that retention of $\mathrm{Ni}$ (by canopy, vegetation, soil) took place at both the Hietajärvi plots, whereas at the Valkea-Kotinen plot the Ni flux at $40 \mathrm{~cm}$ depth in soil was greater than the total inputs (TF $+\mathrm{LF}$ ) (Figure 2). Furthermore, if the internal fluxes $(\mathrm{TF}+\mathrm{LF})$ are ignored, retention of the atmospheric Ni took place only at one of the two Hietajärvi plots.

At the catchment scale, Ni outputs from Valkea-Kotinen and Hietajärvi were less than atmospheric inputs (Table 2), indicating that much of the atmospheric inputs were retained within the catchments. Most of the retention at Hietajärvi and Valkea-Kotinen was associated with the terrestrial part of the catchment, which includes retention in the tree canopy, as well as in soil and uptake and accumulation into plant biomass. As the stands at both Valkea-Kotinen and Hietajärvi are old growth forest, the net increment growth can be considered close to zero [109] and therefore net uptake of elements by trees is negligible. Assuming that the whole upland forested area of the catchments acts as indicated by the 
a)

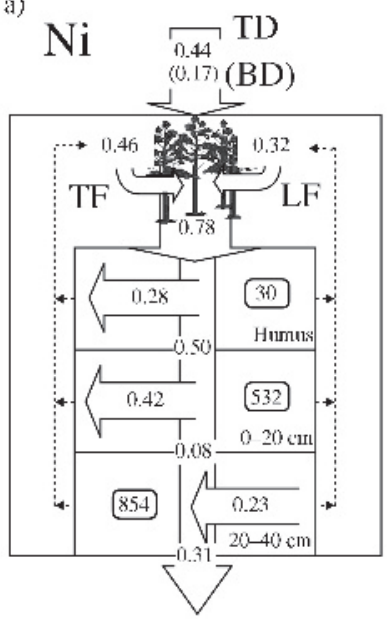

Hielajärvi, plot I

c)

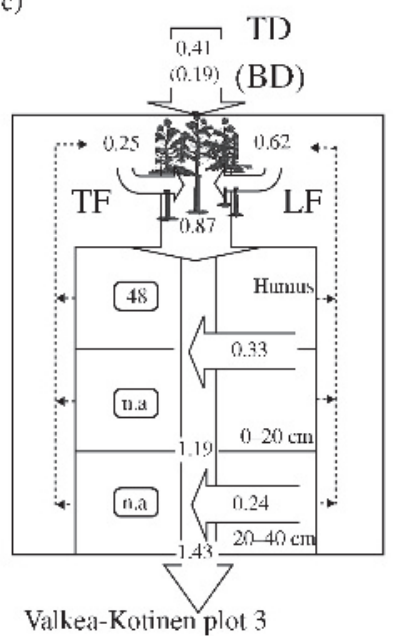

b)

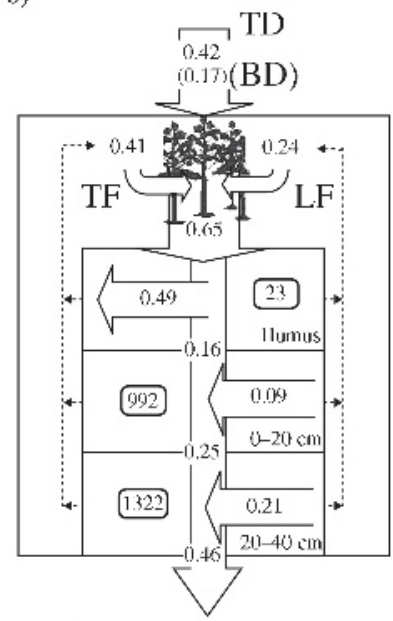

Hielajărvi, plot 4

$$
\begin{aligned}
& \text { Symbols } \\
& 280.9 \text { Soil powl } \mathrm{mg}^{2} \mathrm{~m}^{2} \mathrm{yr}
\end{aligned}
$$

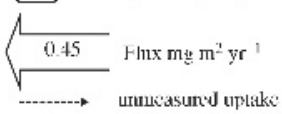

$$
\begin{aligned}
& \text { TD = Tolal Deposition } \\
& \mathrm{BI}=\mathrm{Bulk} \text { Ikpessition } \\
& \text { TF }=\text { Thırsughafall } \\
& \text { L.F = Littcrfal } \\
& \text { 11.i not. available }
\end{aligned}
$$

Figure 2. Plot-scale annual (1994-1996) average input fluxes and output budgets of Ni for: (a) Hietajärvi plot 1; (b) Hietajärvi plot 4; and (c) Valkea-Kotinen plot 1. Reprinted from [108] with permission from Elsevier.

plot scale budgets, i.e., Ni leaching $>$ atmospheric inputs of Ni (Figure 2b, c), most of the Ni retention in the terrestrial part of the catchment takes place below a depth of $40 \mathrm{~cm}$ in the soil profile. Retention of $\mathrm{Ni}^{2+}$ can take place in $\mathrm{B}$ horizon, where cation-adsorbing $\mathrm{Al}$ and Fe hydroxides/oxides are enriched. There are 
Table 2. Mean annual (1994-1996) Ni input-output budgets, retention of atmospheric inputs and transfer of Ni in the Valkea-Kotinen and Hietajärvi catchments in remote areas in Finland. ${ }^{a}$

\begin{tabular}{lcc}
\hline & Valkea-Kotinen & Hietajärvi \\
\hline Catchment area $\left(\mathrm{km}^{2}\right)$ & 0.3 & 4.6 \\
Bulk deposition $\left(\mathrm{mg} \mathrm{m}^{-2} \mathrm{yr}^{-1}\right)$ & 0.19 & 0.17 \\
Total deposition (input) $\left(\mathrm{mg} \mathrm{m}^{-2} \mathrm{yr}^{-1}\right)$ & 0.35 & 0.33 \\
Runoff water (output) $\left(\mathrm{mg} \mathrm{m}^{-2} \mathrm{yr}^{-1}\right)$ & 0.16 & 0.05 \\
Output/input (\%) & 46 & 16 \\
Retention (input - output) $\left(\mathrm{mg} \mathrm{m}^{-2} \mathrm{yr}^{-1}\right)$ & 0.19 & 0.28 \\
Relative retention (input - output/input) $(\%)$ & 54 & 84 \\
Deposition to terrestrial area $\left(\mathrm{g} \mathrm{yr}^{-1}\right)$ & 99 & 1370 \\
Deposition to lake $\left(\mathrm{g} \mathrm{yr}^{-1}\right)$ & 7 & 144 \\
Terrestrial retention (\%) & 88 & 85 \\
Lake retention (\%) & 12 & 15 \\
Terrestrial transfer to lake $\left(\mathrm{g} \mathrm{yr}^{-1}\right)$ & 48 & 285 \\
\hline
\end{tabular}

${ }^{a}$ Adapted with permission from Elsevier from [108].

considerable areas of peatlands in both catchments, which may be very important to the terrestrial retention observed. Sedimentation of organometal complexes is the main process by which heavy metals are retained within lakes $[106,110,111]$.

\section{HISTORICAL RECORDS OF NICKEL DEPOSITION}

\subsection{Sediment}

The chronological geochemical record contained within sediments has been used worldwide to describe the history of contamination [112]. Lake sediments have not only shown the intensity of $\mathrm{Ni}$ pollution in the surroundings of the world's largest Ni smelters at the Kola Peninsula in Russia [113] and at Sudbury in Canada [114] within the last century, but also the recent recovery of lakes reflected in the decreasing concentrations of $\mathrm{Ni}$ in the most recent layers. Lake sediments have also shown that the impact of these smelting activities is primarily localized rather than regional [115]. The release of Ni from industrial areas into the environment in the 1970s/1980s, and the recent decline is well recorded in delta systems, such as that of the Danube [116] and the Venice lagoon [117]. The slight enrichment of $\mathrm{Ni}$ in recent sediment layers of the Culiacan river estuary in Northwestern Mexico was related to population growth [118].

Studies in the UK have shown that even relatively remote sites have experienced enhanced atmospheric deposition of anthropogenically derived Ni for over 
100 years, and the contamination might have started before industrialisation [119]. Sediment records from a remote subalpine lake in Taiwan covering a time span of $2600 \mathrm{yr}$ indicated that aeolian Asian dust particles have played a significant role in the elevated deposition of $\mathrm{Ni}$ during dry periods [120]. The natural enrichment of $\mathrm{Ni}$ (up to $0.1 \% \mathrm{Ni}$ ) in a lake sediment core from Finland was related to the prolonged erosion of metalliferous black shales during glacial retreat ca 9000 years ago [121].

\subsection{Peat Bog}

Ombrotrophic peat cores have recently proved to be meaningful archives of recent as well as ancient atmospheric metal deposition, especially for $\mathrm{Pb}[122$ 124] and $\mathrm{Hg}$ [125-128]. In contrast, there are only a few systematic studies on the distribution and fate of $\mathrm{Ni}$ in ombrotrophic bogs [129-134]. The results indicate that the fate of $\mathrm{Ni}$ is strongly dependent upon the mineralogical form in which it is originally deposited, but also on the geochemical and hydrological conditions in the peat layers, and the peat accumulation rate [133]. Due to the high deposition rate of $\mathrm{Ni}$ near a $\mathrm{Cu}-\mathrm{Ni}$ smelter, recent smelter emissions are to some extent recorded in the peat profile [132]. In the long term, however, the bulk of deposited particles are expected to dissolve in the peat layers [134]. Even the emission of $\mathrm{Ni}$ sulfide particles from a nearby $\mathrm{Ni}$ mine was not well reflected in the peat profile, although these minerals had been expected to be chemically stable in the anoxic peat layers [132]. The crucial factor might be the early oxidation of particles in the aerated surface layers of the bog [133].

The retention of anthropogenic $\mathrm{Ni}$ from long-range atmospheric transport shows some (apparent) inconsistencies [129,130,132]. In a peat core taken at a low-background area in Finland, post-depositional processes could not be excluded [132]. In contrast, the deposition of dust-related $\mathrm{Ni}$ phases appeared to be well preserved in an age-dated Swiss peat core (Figure 3) [129]. The highest concentrations of $\mathrm{Ni}$ were found during the Younger Dryas cold climate event (centered at 10590 yr B.P. according to ${ }^{14} \mathrm{C}$ dating) when background values were exceeded by about 40 times. Elevated $\mathrm{Ni}$ accumulation rates were also found at 8230 and 5320 years B.P. according to ${ }^{14} \mathrm{C}$ dating, which are consistent with the elevated dust fluxes recorded by Greenland ice cores. Silicate mineral particles are well preserved in acidic peat for thousands of years [135]. Apparently, when silicate phases are the main Ni-bearing host, $\mathrm{Ni}$ is well preserved in the peat profile.

\subsection{Polar Snow and Ice}

Ice cores have provided much important information about temporal trends in atmospheric metal deposition in Greenland [137-139], the European Alps [140], and Antarctica [141]. However, to the best of our knowledge, there is only one 

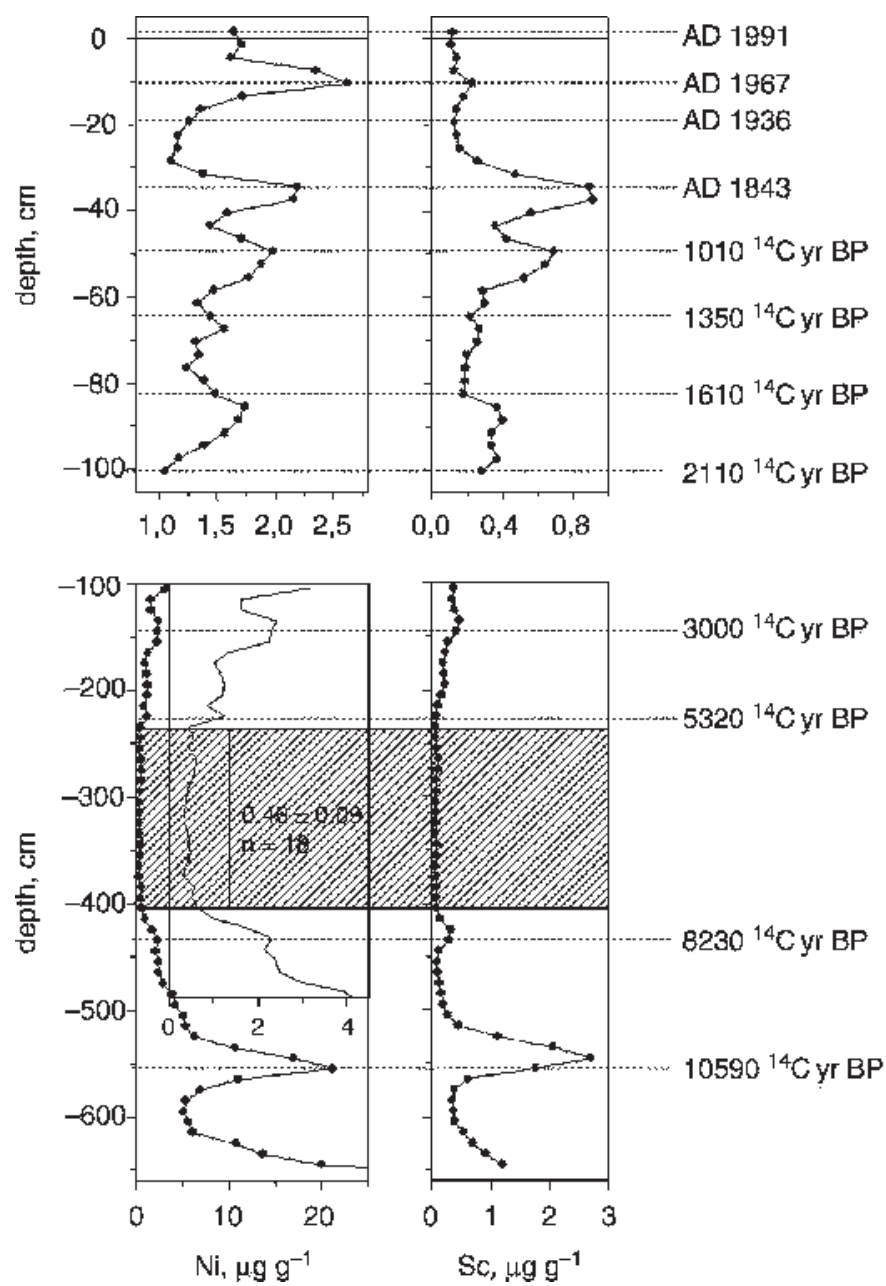

Figure 3. Nickel and scandium concentrations in a Swiss peat core. The shaded area (ca. 5320-8230 years B.P. according to ${ }^{14} \mathrm{C}$ dating) corresponds to the Holocene Climate Optimum when rates of atmospheric soil dust deposition were at their lowest $[122,136]$. Times of high dust deposition are indicated by elevated Sc concentrations in the peat [136]. Reprinted from [129] with permission from the American Chemical Society.

single study which includes Ni concentration data [142]. Nickel concentrations of a 12.5-m-long ice core from Devon Island, Canadian Arctic, ranged between 0.6 and $144 \mathrm{pg} \mathrm{g}^{-1}$. The wide dispersion of concentration values is highly dependent on variations due to the strong seasonal influence on the mechanism of atmospheric transportation [142]. 


\section{BIOAVAILABILITY AND MOBILITY OF NICKEL IN SOILS}

\subsection{Uptake and Translocation of Nickel by Plants}

Nickel is a natural constituent of plant tissues ranging normally from 0.05 to $10 \mu \mathrm{g} \mathrm{g}^{-1}$ of dry matter [7,143]. The range in concentrations mainly reflects the differences between plant species in uptake and in root-to-shoot transport of $\mathrm{Ni}$ [143]. Although threshold concentrations for the lethal Ni toxicity are commonly reported to be less than $100 \mu \mathrm{gg}^{-1}$ [7,71,144-146], Ni concentrations as high as $600 \mu \mathrm{g} \mathrm{g}^{-1}$, have been found in leaves of maples (Acer spp.) growing close to the Port Colborne Ni refinery in Ontario, Canada [147] and $\sim 580 \mu \mathrm{g} \mathrm{g}^{-1}$ in Scots pine needles of tree stands in the vicinity of a $\mathrm{Cu}-\mathrm{Ni}$ smelter in Finland [148]. Such high values are mostly due to surface contamination of the field-grown plants by Ni-containing dust. However, it is also well known that certain endemic plant species growing on ultramafic soils, the so-called hyperaccumulators, can contain more than $1000 \mu \mathrm{g} \mathrm{Ni} \mathrm{g}^{-1}$ inside their tissues [149] (see also Chapter 2). In a Scots pine stand growing close to a $\mathrm{Cu}-\mathrm{Ni}$ smelter, more than half of the $\mathrm{Ni}$ in precipitation originated from the wash-off of canopy-deposited dust [150] and pine needles exposed to aerial deposition contained tens of times more Ni than the needles protected from this source [148]. The measured Ni concentrations of boreal plant species growing naturally in Ni polluted forests are variable (Table 3), which may be, at least partly, due to varying degrees of surface contamination.

Although root uptake is the main pathway for Ni access in higher plants, there is much evidence showing that $\mathrm{Ni}$ is also available to plants through the foliage both in conditions of excess $\mathrm{Ni}[153,154]$ and Ni deficiency [155]. Bryophytes and lichens are especially efficient in absorbing elements directly across their surfaces because they have neither epidermis or cuticle layer, nor roots [156]. Not surprisingly, therefore mosses and lichens are widely used as biomonitors of metals (see also Section 5.2).

Most of the Ni deposited on foliar surfaces does not penetrate into the living cells through the cuticle of higher plants, and therefore does not have direct toxic effects on metabolism. Consequently, the Ni concentrations of field-grown plants are usually of little relevance in terms of a plant's physiological response, even though they can be important in assessing risks to animals or humans. Washing of plant material prior to analysis is often recommended as a means to remove or separate the particulate materials contaminating plant surfaces [157]. However, in studies by Kozlov et al. [158], as well as by Nieminen et al. [148] only a minor part of surface-deposited $\mathrm{Ni}$ on tree foliage was removed by washing.

The secretion of organic compounds by plant roots may affect the solubility of $\mathrm{Ni}$ in the rhizosphere soil $[143,159]$. There are several examples showing that the presence of other compounds in the substrate can either increase or decrease the Ni uptake, depending on their quantity, quality, and the characteristics of the plant in question. Nickel uptake by Scots pine seedlings grown in quartz-sand 
Table 3. Nickel concentration of some boreal plant species near the $\mathrm{Cu}-\mathrm{Ni}$ smelter at Harjavalta (Finland), the Ni smelter at Monchegorsk (Kola Peninsula, Russia) and a background site in Finland.

\begin{tabular}{|c|c|c|}
\hline Species & & $\mathrm{Ni}\left(\mu \mathrm{gg}^{-1}\right)$ \\
\hline \multicolumn{3}{|l|}{ Near the smelters } \\
\hline Vaccinium myrtillus $\mathrm{L}^{a}$ & & 959 \\
\hline Vaccinium vitis-idaea L. $^{a}$ & & 945 \\
\hline Vaccinium vitis-idaea L. $^{b}$ & & 22 \\
\hline Empetrum nigrum L. ${ }^{b}$ & & 54 \\
\hline Deschampsia flexuosa L. (Trin.) ${ }^{a}$ & & 1452 \\
\hline \multirow[t]{3}{*}{ Pinus sylvestris L., needles ${ }^{c}$} & 1-year-old & 44 \\
\hline & 2-year-old & 49 \\
\hline & 3-year-old & 44 \\
\hline \multicolumn{3}{|l|}{ Background } \\
\hline Vaccinium myrtillus $\mathrm{L}^{d}{ }^{d}$ & & 4.8 \\
\hline Vaccinium vitis-idaea L. $^{d}$ & & 3.5 \\
\hline Empetrum nigrum L. ${ }^{d}$ & & 5.2 \\
\hline Deschampsia flexuosa L.(Trin. $)^{d}$ & & 11.8 \\
\hline \multirow[t]{3}{*}{ Pinus sylvestris L., needles ${ }^{e}$} & 1-year-old & 3.8 \\
\hline & 2-year-old & 2.3 \\
\hline & 3 -year-old & 1.8 \\
\hline
\end{tabular}

${ }^{a} 2 \mathrm{~km}$ from the Ni smelter, Kola Peninsula, Russia [151].

${ }^{b} 2 \mathrm{~km}$ from the $\mathrm{Cu}-\mathrm{Ni}$ smelter, Harjavalta, Finland [152].

${ }^{c} 0.5 \mathrm{~km}$ from the $\mathrm{Cu}-\mathrm{Ni}$ smelter, Harjavalta, Finland [150].

${ }^{d}$ Background value from Finland [152].

${ }^{e}$ Unpublished data from the Finnish Forest Research Institute.

substrate was enhanced in the presence of copper [146], while Cataldo et al. [160] found that Ni absorption by hydroponically grown soybean plants (Glycine max (L.) Merr. cv. Williams) was completely inhibited in the presence of $\mathrm{Cu}$. Singh et al. [161] observed that an increasing supply of urea appeared to mitigate the toxicity of Ni to wheat (Triticum aestivum L.). The presence of organic acids or inorganic ligands in soil solution results in formation of Ni complexes, which may either inhibit or enhance root uptake, depending on the characteristics of the $\mathrm{Ni}$ complex formed. For example, Molas [162] reports that Ni(II)-EDTA was less enriched and less toxic than $\mathrm{Ni}$ (II)-citrate or $\mathrm{Ni}$ (II)-Glu to hydroponically grown cabbage plants. Generally, the ionic form of $\mathrm{Ni}^{2+}$ is taken up relatively easily by plants, but many chelated forms appear to be less available $[160,163]$. Highmolecular-weight solutes are prevented from entering the apoplasm of root cells by the diameter of pores [143]. Plants can restrict the apoplastic passage through the establishment of a suberin-rich transport barrier in the roots [164]. 
Although $\mathrm{Ni}$ is generally considered to be a readily mobile element in plants $[8,143]$, the mobility within a plant is regulated by the formation of organic $\mathrm{Ni}$ complexes [165]. According to Tiffin [166] Ni is present in anionic organic complexes in the xylem of most plant species, which suggests that $\mathrm{Ni}$ is chelated by an organic ligand (carrier) before translocation to the shoot. Timperley et al. [167] reported that $\mathrm{Ni}$ in the foliage of several tree species was mainly complexed, and either in a neutral or positively charged species. In some plant species, e.g., oat (Avena sativa L.) and legume species (Fabaceae) associated with Rhizobium bacteria such as peas and beans, $\mathrm{Ni}$ is primarily enriched in the seeds [71,143]. Cataldo et al. [168] concluded that the leaves of soybean plants were a major sink during vegetative growth, while more than $70 \%$ of the $\mathrm{Ni}$ in shoot was remobilized to the seeds at senescence. During autumnal senescence, $5-20 \%$ of the $\mathrm{Ni}$ incorporated in the senescent needle mass was translocated to the remaining tissues of adult Scots pine trees growing in conditions of excess Ni [169].

\subsection{Importance of Partitioning for Bioavailability and Mobility}

Total Ni contents in the soil might depict the potential availability of $\mathrm{Ni}$, but in most cases the total content is of little relevance in terms of $\mathrm{Ni}$ availability. The basic aim of a number of soil extraction schemes is to estimate the metal pool available to plants or other soil biota [170]. Single extractants such as dilute acids $\left(\mathrm{HCl}, \mathrm{NH}_{4}^{+}, \mathrm{HNO}_{3}\right.$ ) or solutions containing chelating agents (DTPA or EDTA) are traditionally used to estimate the bioavailable proportion of soil metal [7]. However, when applied to soils with a wide range of soil characteristics, they fail to predict metal bioavailability adequately [171]. In addition to the mineralogical form of a metal, the key properties controlling its solubility and availability are soil solution $\mathrm{pH}$, dissolved organic matter, and solid-phase metal oxide and organic matter content [172].

In general, the solubility of $\mathrm{Ni}$ is inversely related to the soil $\mathrm{pH}$ [8], albeit this dependence may be affected by organic complexation. Poulsen and Hansen [173] examined the influence of citrate and arginine on Ni sorption to a sandy loam soil and its dependence on $\mathrm{pH}$. As the sorption edges for $\mathrm{Ni}$ without ligands showed $50 \%$ sorption at approximately $\mathrm{pH} 5$, the presence of citrate depressed sorption, with the $50 \%$ sorption shifting to a $\mathrm{pH}$ value of more than 7.5. In contrast, arginine had almost no influence on sorption over the entire $\mathrm{pH}$ range studied. Poulsen and Hansen [173] concluded that the trivalent nickel-arginine complexes $\left(\mathrm{NiH}_{3} \mathrm{arg}_{2}^{3+}\right)$ were sorbed to cation exchange sites, while sites for the bonding of monovalent negatively charged nickel-citrate complexes $\left(\mathrm{Nicit}^{-}\right)$were sparse. According to Wolt [174] and Kabata-Pendias [8], humic and fulvic acids, as well as simple carboxylic acids derived from the decomposition of organic matter, are sufficiently abundant in soil solutions and form complexes with $\mathrm{Ni}$ of sufficient 
stability, that these can have comparable effects on Ni sorption as citrate. These processes might explain the mobility of $\mathrm{Ni}$ in podzolic soils impacted by atmospheric Ni pollution [175].

The aim of the so-called sequential extraction techniques [176,177] is to dissolve various solid fractions step by step and to liberate the metals associated with each fraction, starting with the most accessible fractions and sequentially dissolving the increasingly recalcitrant fractions by using increasingly aggressive reagents. According to the results of sequential extractions most of the $\mathrm{Ni}$ in soils should be associated with iron and manganese oxides (reducible fraction), as well as with the residual fraction [178-180]. However, the reagents used in these sequential techniques can never affect only a single fraction, and these results have always to be interpreted with caution. Furthermore, there is no evidence indicating which solid-phase fraction correlates best with uptake by organisms [171]. Element partitioning may be further modified in the rhizosphere and within the digestive tract of soil-dwelling organisms [172]. In the case of soil invertebrates, extractant methods that attempt to mimic their digestive processes would be the most suitable ones to predict the availability of soil $\mathrm{Ni}$ to them.

Since plants access metals in the soil principally through the soil solution, it might be reasonably expected that the determination of $\mathrm{Ni}$ concentrations in the soil solution would provide the best predictor of Ni availability to plants. However, the prediction capacity of soil solution concentrations is not yet clear. Although the relatively high $\mathrm{Ni}$ concentration in soil percolation water was interpreted as reflecting higher downward leaching of $\mathrm{Ni}$ compared with $\mathrm{Cu}$ in forest soils adjacent to $\mathrm{Cu}-\mathrm{Ni}$ smelters [175], Ni uptake by Scots pine roots did not appear to be more efficient than that of $\mathrm{Cu}[146,181]$.

In most $\mathrm{Ni}$ exposure experiments in which plants have been grown hydroponically, the Ni concentrations are often so high that the results do not have any ecological relevance. Toxic threshold concentrations of nutrient solutions reported by Mishra and Kar [163] vary from 0.5 to $300 \mathrm{mg} \mathrm{L}^{-1}$ depending on the plant species in question, whereas Ni concentrations in soil solutions taken from a dead Scots pine stand next the $\mathrm{Ni}-\mathrm{Cu}$ smelters at Monchegorsk in the Kola Peninsula (Russia) ranged from 0.1 to $2.9 \mathrm{mg} \mathrm{L}^{-1}$ [3]. The total Ni concentration (dry ashing and $\mathrm{HCl}$ extraction) in the topmost organic layer of the same pine stand was ca. $3000 \mu \mathrm{g} \mathrm{g}^{-1}$ of organic matter [182] and $\sim 70 \mu \mathrm{g} \mathrm{g}^{-1}$ of dry matter in the mineral soil horizons [183]. An average value of $20 \mathrm{mg} \mathrm{kg}^{-1}$ for $\mathrm{Ni}$ of world soils, and a range of $5-500 \mathrm{mg} \mathrm{Ni} \mathrm{kg}^{-1}$, have been reported by Adriano [7]. However, in ultramafic soils, which are naturally enriched by $\mathrm{Ni}$, values ranging from 100 to $3000 \mathrm{mg} \mathrm{Ni} \mathrm{kg}^{-1}$ have been reported in the UK and Scandinavia [184]. According to Tamminen [185] the median concentration of $\mathrm{Ni}$ in the organic layer of upland forest soil in Finland is $8.2 \mu \mathrm{g} \mathrm{g}^{-1}$ of dry matter. 


\section{SUMMARY AND CONCLUSIONS}

During the last century Ni concentrations in soils and sediments increased worldwide. Nickel is frequently enriched in oil and coal, and oil combustion is currently the largest source of atmospheric $\mathrm{Ni}$ by far, although $\mathrm{Ni}$ emissions from mining and smelting activities have caused extensive damage in the areas surrounding large industrial complexes. Nickel is a valuable metal for modern industry, mostly due to its expanding need as a crucial component of stainless steel.

The environmental mobility of $\mathrm{Ni}$ is considered to be low under neutral to alkaline and reducing conditions, but in acidic organic rich soils where Ni can be quite mobile, Ni contamination may pose a risk to groundwater quality. Even though the ionic form of $\mathrm{Ni}^{2+}$ is taken up relatively easily by plants, chelated highmolecular-weight compounds are less available. Therefore, Ni does not appear to be subjected to biomagnification in terrestrial food webs, with the exception of the $\mathrm{Ni}$ hyperaccumulating plants. However, frequent application of sewage sludge on agricultural fields may result in substantial Ni absorption by some crop plants.

Although $\mathrm{Ni}$ is an essential minor element, it is toxic in excess doses. Until now there has been more concern about the toxicity than possible deficiencies of $\mathrm{Ni}$. Nevertheless, knowledge of the mechanisms underlying both the deficiency and toxicity of $\mathrm{Ni}$ have remained relatively limited. The content of the following Chapters of this book is intended to help fill these gaps and to increase our understanding of the relationships between Ni and organisms.

\section{ABBREVIATIONS}

\begin{tabular}{|c|c|}
\hline AAS & atomic absorbtion spectrometry \\
\hline AFS & atomic fluorescence spectrometry \\
\hline AMAP & Arctic Monitoring and Assessment Program \\
\hline $\mathrm{BC}$ & before Christ \\
\hline B/C-horizon & mineral and parent material horizon \\
\hline BD & bulk deposition \\
\hline BP & before present \\
\hline $\mathrm{CE}$ & capillary electrophoresis \\
\hline DTPA & diethylenetriaminepentaacetate \\
\hline EDTA & ethylenediamine- $N, N, N^{\prime}, N^{\prime}$-tetraacetatic acid \\
\hline $\mathrm{EF}$ & enrichment factor \\
\hline Eh & standard potential \\
\hline EMEP & $\begin{array}{l}\text { Co-operative Programme for Monitoring and Evaluation of the } \\
\text { Long-Range Transmission of Pollutants in Europe }\end{array}$ \\
\hline EMPA & electron microprobe analyzers \\
\hline EPA & Environmental Protection Agency \\
\hline
\end{tabular}

Met. Ions Life Sci. 2, 1-30 (2007) 


$\begin{array}{ll}\text { ICP-MS } & \text { inductively coupled plasma mass spectrometry } \\ \text { ICP-OES } & \text { inductively coupled plasma optical emission spectrometry } \\ \text { LF } & \text { litterfall } \\ \text { LOD } & \text { limit of detection } \\ \text { TF } & \text { throughfall } \\ \text { TD } & \text { total deposition } \\ \text { UV } & \text { ultraviolet radiation } \\ \text { WHO } & \text { World Health Organization } \\ \text { WQC } & \text { water quality criteria } \\ \text { XAFS } & \text { X-ray fine-structure analysis } \\ \text { XANES } & \text { X-ray absorbtion near-edge structure } \\ \text { XRF } & \text { X-ray fluorescence spectrometry }\end{array}$

\section{REFERENCES}

1. J. O. Nriagu, Environment, 32, 7-33 (1990).

2. E. G Pacyna and J. M. Pacyna, Environmental Reviews, 9, 269-298 (2001).

3. A.-J. Lindroos, J. Derome, V. Nikonov, and K. Niska, Scand. J. For. Res., 11, 97-103 (1996).

4. Å. Rühling, E. Steinnes, and T. Berg, Nord, 37, 1-47 (1996).

5. J. M. Pacyna and B. Ottar, Atmos. Environ., 19, 2109-2120 (1985).

6. J. O. Nriagu and J. M Pacyna, Nature, 333, 134-139 (1988).

7. D. C. Adriano, Trace Elements in Terrestrial Environments, 2nd edn, Springer, New York, 2001, pp. 1-867.

8. A. Kabata-Pendias, Trace Elements in Soils and Plants, 3rd edn, CRC, Boca Raton, 2001, pp. 1-448.

9. D. G. Brookins, Eh-pH Diagrams for Geochemistry, Springer, New York, 1988, pp. 70 .

10. K. K. Turekian and K. H. Wedepohl, Geolog. Soc. Am. Bull., 72, 175-192 (1961).

11. G. Tao, R. Yamada, Y. Fujikawa, A. Kudo, J. Zheng, D. A. Fisher, and R. M. Koerner, Talanta, 55, 765-772 (2001).

12. EPA, SW-846, Method 7520, Nickel (atomic absorption, direct aspiration), Washington, 1986.

13. EPA, SW-846, Method 7521, Nickel (atomic absorption, furnace method), Washington, 1996.

14. EPA, Method 1640, Determination of trace elements in water by preconcentration and inductively coupled plasma-mass spectrometry, Washington, 1997.

15. M. Tuzen, M. Soylak, and L. Elci, Anal. Chim. Acta, 548, 101-108 (2005).

16. M. L. Wells and K. W. Bruland, Marine Chem., 63, 145-153 (1998).

17. J. Otero-Romaní, A. Moreda-Piñeiro, A. Bermejo-Barrera, and P. Bermejo-Barrera, Anal. Chim. Acta, 536, 213-218 (2005).

18. H. Bag, A. R. Türker, R. Cogkun, M. Saçak, and M. Yigitoglu, Spectrochim. Acta $B, 55,1099-1106$ (2000). 
19. N. Tokman, S. Akman, and M. Ozcan, Talanta, 59, 201-205 (2003).

20. K. Suvardhan, K. S Kumar, D. Rekha, B. Jayaraj, G. K. Naidu, and P. Chiranjeevi, Talanta, 68, 735-740 (2006).

21. S. Baytak and A. R. Türker, J. Hazardous Materials, 129, 130-136 (2006).

22. S. Saraçoglu and L. Elçi, Anal. Chim. Acta, 452, 77-83 (2002).

23. P. Daorattanachai, F. Unob, and A. Imyim, Talanta, 67, 59-64 (2005).

24. A. Ersöz, R. Say, and A. Denizli, Anal. Chim. Acta, 502, 91-97 (2004).

25. H. H. Chen and D. Beauchemin, J. Anal. Atom. Spectrom., 16, 1356-1363 (2001).

26. Ü. Divrikli and L. Elçi, Anal. Chim. Acta, 452, 231-235 (2002).

27. N. Rausch, L. Ukonmaanaho, T. M. Nieminen, M. Krachler, G. Le Roux, and W. Shotyk, Anal. Chim. Acta, 558, 201-210 (2006).

28. M. Felipe-Sotelo, A. Carlosena, J. M. Andrade, M.J. Cal-Prieto, E. Fernández, and D. Prada, Microchem. J., 81, 217-224 (2005).

29. J. P. Pancras, J. M. Ondov, and R. Zeisler, Anal. Chim. Acta, 538, 303-312 (2005).

30. F. Vanhaecke and L. Moens, Fresenius J. Anal. Chem, 364, 364-451 (1999).

31. A. Von Bohlen, H. Brink-Kloke, and C. Althoff, Anal. Chim. Acta, 480, 327-335 (2003).

32. A. C. M. Costa, M. J. Anjos, S. Moreira, R. T. Lopes, and E. F. O. de Jesus, Spectrochim. Acta B, 58, 2199-2204 (2003).

33. A. K. Cheburkin and W. Shotyk, Fresenius J. Analyt. Chem., 354, 688-691 (1996).

34. D. Grolimund, M. Senn, M. Trottmann., M. Janousch., I. Bonhoure, A. M. Scheidegger, and M. Marcus, Spectrochim. Acta B, 59, 1627-1635 (2004).

35. A. Manceau, C. Tommaseo, S. Rihs, N. Geoffroy, D. Chateigner, M. Schlegel, D. Tisserand, M. A. Marcus, N. Tamura, and Z. Chen, Geochim. Cosmochim. Acta, 69, 4007-4034 (2005).

36. A. Manceau, N. Tamura, M. A. Marcus, A. A. MacDowell, R. S. Celestre, R. E. Sublett, G. Sposito, and H. A. Padmore, Am. Mineralogist, 87, 1494 (2002).

37. S. Hlawatsch, C. D. Garbe-Schönberg, F. Lechtenberg, A. Manceau, N. Tamura, D. A. Kulik, and M. Kersten, Chem. Geol., 182, 697-709 (2002).

38. H. B. Xue and L. Sigg, in Environmental Electrochemistry: Analyses of Trace Element Biogeochemistry (T. F. Rozan and M. Taillefert, eds), American Chemical Society, Washington, 2002, pp. 336-370.

39. M. M. Ghoneim, A. M. Hassanein, E. Hammam, and A. M. Beltagi, Fresenius J. Anal. Chem., 367, 378-383 (2000).

40. V. M. C. Herzl, G. E. Millward, R. Wollast, and E. P. Achterberg, Estuarine Coastal Shelf Sci., 56, 43-52 (2003).

41. R. E. Shepherd, Coord. Chem. Rev., 247, 147-184 (2003).

42. C. Reimann, M. Äyräs, V. Chekushin, I. Bogatyrev, R. Boyd, P. de Caritat, R. Dutter, T. E. Finne, J. H. Halleraker, Ø. Jæger, G. Kashulina, O. Lehto, H. Niskavaara, V. Pavlov, M. L. Räisänen, T. Strand, and T. Volden, Environmental Geochemical Atlas of the Central Barents Region, Grytting As, Norway, 1998, pp. 422-425.

43. WHO, Air Quality Guidelines for Europe, Chapter 6.10, Nickel, WHO Regional Office for Europe, Copenhagen, Denmark, 2000.

44. J. Mannio, R. Salminen, S. Leppänen, U. Väisänen, P. Räinä, J. Poikolainen, E. Kubin, J. Piispanen, and M. Verta, Suomen ympäristö, 581, 29-49 (2002).

45. M. Melanen, M. Ekqvist, A. B. Mukherjee, L. Aunela-Tapola, M. Verta, and T. Salmikangas, Suomen ympäristö, 329, 1-86 (1999). 
46. A. B. Mukherjee, Environ. Rev., 6, 173-187 (1998).

47. AMAP, in Arctic Pollution Issues: A State of the Arctic Environment Report, Arctic Monitoring and Assessment Programme, Oslo, 1997, pp. 1-188.

48. R. M. Hoff and L. A. Barrie, Water Sci. Technol., 18, 97-107 (1986).

49. W. H. Chan and M. A. Lusis, Adv. Environ. Sci. Technol., 17, 113-143 (1986).

50. L. Leinonen (ed.), Air Quality Measurements 1996, Finnish Meteorological Institute, Helsinki, 1998, pp.1-244.

51. L. Leinonen (ed.), Air Quality Measurements 1997, Finnish Meteorological Institute, Helsinki, 1999, pp. 1- 251.

52. L. Leinonen (ed.), Air Quality Measurements 1998, Finnish Meteorological Institute, Helsinki, 1999, pp. 1- 256.

53. L. Jalkanen, Finnish Meteorological Institute Contributions, 29, 1-20 (2000).

54. Southwest Finland Regional Environment Centre, Harjavalta Copper Oy Environmental Permit, LSY-2002-Y-361, Helsinki, 2004, pp. 1-153.

55. B. J. Bennett, in Nickel in the Human Environment (F. W. Sunderman, Jr., ed.), Lyon, 1994, pp. 487-495.

56. H. J. M. Bowen, Environmental Chemistry of the Elements, Academic Press, London, 1979, pp. 1-333.

57. W. Aas and A.-G. Hjellebrekke, EMEP/CCC-Report 1/2003, Norwegian Institute for Air Research, 2003, pp. 1-114.

58. J. Derome, Finnish Forest Research Institute Research Papers 769, 1-78, (2000).

59. A. Ruhling and G. Tyler, Botaniska Notiser, 122, 248-342 (1968).

60. G. Tyler, Moss-analysis - A Method for Surveying Heavy Metal Deposition, Proc. Second Int. Clean Air Congress, New York, 1970, pp. 129-132.

61. E. Steinnes, J. Radioanal. Chem., 58, 387-391 (1980).

62. A. Mäkinen, Symposia Biologica Hungarica, 35, 777-794 (1983).

63. R. Gjegedal and E. Steinnes, Environ. Monitoring and Assess., 14, $77-87$ (1990).

64. E. Steinnes, Sci. Tot. Environ, 160/161, 243-249 (1995).

65. H. G. Zechmeister, K. Grodzinska, and G. Szarek-Lukaszewska, in Bioindicators and Biomonitors (B. A. Markert, A. M. Breure, and H. G. Zechmeister, eds), Oxford, 2003, pp. 329-375.

66. Å. Ruhling and G. Tyler, Water Air Soil Poll., 2, 445-455 (1973).

67. Å. Rühling, L. Rasmussen, K. Pilegaard, A. Mäkinen, and E. Steinnes, Nord, 21, 1-44 (1987).

68. J. Poikolainen, E. Kubin, J. Piispanen, and J. Karhu, Sci. Total Environ., 318, 171185 (2004).

69. M. Salemaa, I. Vanha-Majamaa, and J. Derome, Environ. Pollut., 112, 339-350 (2001).

70. Å. Rühling, Nord, 9, 1- 53 (1994).

71. W. D. McIlveen and J. J. Negusanti, Sci. Tot. Environ, 148, 109-138 (1994).

72. J. O. Nylander, Lettres Botaniques, 13, 364-372 (1866).

73. V. V. Kryuchkov, Degradation of Ecosystems around the Severinikel Smelter Complex, Aerial Pollution in Kola Peninsula: Proceeding of the International Workshop, St. Petersburg, 1993, pp. 35-46.

74. C. Reimann, J. H. Halleraker, G. Kashulina, and I. Bogatyver, Sci. Tot. Environ., 243/244, 169-191 (1999). 
75. M. H. Martin and P. J. Coughtrey, Biological Monitoring of Heavy Metal Pollution, Applied Science Publishers, London, 1982, pp. 1-475.

76. J. Garty, in Plants as Biomonitors. Indicators for Heavy Metals in the Terrestrial Environment (B. Markert, ed.), VCH, Weinheim, 1993, pp. 193-263.

77. D. H. Brown and R. P. Beckett, in Lichen Physiology and Cell Biology (D. H. Brown, ed.), London Plenum Press, 1985, pp. 247-258.

78. D. H. S. Richardson, Symbiosis, 18, 119-127 (1995).

79. G. P. O'Hare and P. Williams, Lichenologist, 15, 89-93 (1975).

80. K. Pilegaard, L. Rasmusseen, and H. Gydesen, J. Appl. Ecology, 16, 843-853 (1979).

81. K. Takala, H. Olkkonen, J. Ikonen, J. Jääskeläinen, and P. Puumalainen, Ann. Bot. Fennici, 22, 91-100 (1985).

82. E. Kubin, in Acidification in Finland (P. Kauppi, P. Anttila, and K. Kenttämies, eds) Springer-Verlag, Berlin, Heidelberg, 1990, pp. 421-446.

83. H. Lippo, J. Poikolainen, and E. Kubin, Water Air Soil Poll., 85, 2241-2246 (1995).

84. F. D. Tomassini, K. J. Puckett, E. Nieboer, D. H. S. Richardson, and B. Grace, Can. J. Bot., 54, 1591-1603 (1976).

85. J. Case, An Investigation of the Use of Lichens and Mosses as Biomonitors of Acidic Precipitation in Ontario, Report No. ARB-180-Phyto, Ontario Ministry of the Environment, Toronto, Canada, 1990, pp.1-124.

86. M. Backor and D. Fahselt, Environ. Exp. Bot., 52, 149-159 (2004).

87. B. Staxäng, Oikos, 20, 224-230 (1969).

88. J. Poikolainen, Water Air Soil Poll., 93, 395-408 (1997).

89. S. Kakulu, Environ. Monit. Assess., 89, 233-242 (2003).

90. T. Tarvainen, P. Lahermo, and J. Mannio, Water Air Soil Poll., 94, 1-32 (1997).

91. T. Nieminen, L. Ukonmaanaho, and W. Shotyk, Sci. Tot. Environ, 292, 81-89 (2002).

92. J. Mannio, P. Porvari, T. Vartiainen, A. Witick, K. Kinnunen, and M. Verta, Lake Sediments as Indicators of Airborne Pollution in Lapland, The AMAP Symposium on Environmental Pollution in the Arctic, Trömsö, Norway, 1997, pp. 410-412.

93. K. Johansson, A. Andersson, and T. Andersson, Sci. Tot. Environ, 160/161, $373-$ 380 (1995).

94. S. Rognerud, T. Skotvold, E. Fjeld, S. A. Norton, and A. Hoback, Can. J. Fish. Aquat. Sci., 55, 1512-1523 (1998).

95. L. Ukonmaanaho, M. Starr, J.-P. Hirvi, A. Kokko, P. Lahermo, J. Mannio, T. Paukola, T. Ruoho-Airola, and H. Tanskanen, Boreal Env. Res., 3, 235-249 (1998).

96. G. Tyler, Water Air Soil Poll., 47, 321-333 (1989).

97. G. Lithner, Sci. Tot. Environ, 87/88, 365-380 (1989).

98. L. R. Peterson, V. Trivett, A. J. M. Baker, C. Aguiar, and A. J. Pollard, Chemoecology, 13, 103-108 (2003).

99. T. Phipps, S. L. Tank, J. Wirtz, L. Brewer, A. Coyner, L. S. Ortego, and A. Fairbrother, Environ. Rev., 10, 209-261 (2002).

100. S. E. Lindberg, G. M. Lovett, D. D. Richter, and D. W. Johnson, Science, 231, 141-145 (1986). 
101. J. E. Fergusson, The Heavy Elements: Chemistry, Environmental Impacts and Health Effects, Pergamon Press, Oxford, 1990, pp. 1-614.

102. S. E. Lindberg and R. R. Turner, Water Air Soil Poll., 39, 123-156 (1988).

103. R. S. Turner, A. H. Johnson, and D. Wang, J. Environ. Qual., 14, 305-314 (1985).

104. J. R. White and C. T. Driscoll, Environ. Sci. Technol., 21, 211-216 (1987).

105. P. H. Schut, D. Evans, and W. A. Scheider, Water, Air, Soil Pollut., 28, 225-237 (1986).

106. P. J. Dillon, H. E. Evans, and P. J. Scholer, Biogeochemistry, 5, 201-220 (1988).

107. M. Aastrup, Å. Iverfeldt, L. Bringmark, H. Kvarnäs, B. Thunholm, and H. Hultberg, Water, Air, Soil Poll., 85, 755-760 (1995).

108. L. Ukonmaanaho, M. Starr, J. Mannio, and T. Ruoho-Airola, Environ. Poll., 114, 63-75 (2001).

109. M. Starr, T. Kinnunen, and M. Hartman, Suomen Ympäristö, 218, 32-36 (1998).

110. B. LaZerte, D. Evans, and P. Grauds, Sci. Tot. Environ, 87/89, 209-221 (1989).

111. M. Verta, K. Tolonen, and H. Simola, Sci. Tot. Environ., 87/88, 1-18 (1989).

112. C. J. von der Heyden and M. G. New, J. Geochem. Explor., 82, 35-57 (2004).

113. A. Lukin, V. Dauvalter, N. Kashulin, V. Yakovlev, A. Sharov, and O. Vandysh, Sci. Tot. Environ., 306, 73-83 (2003).

114. N. Belzile, Y.-W. Chen, J. M. Gunn, and S. S. Dixit, Environ. Poll., 130, 239-248 (2004).

115. S. M. Allen-Gil, J. Ford, B. K. Lasorsa, M. Monetti, T. Vlasova, and D. H. Landers, Sci. Tot. Environ., 301, 119-138 (2003).

116. H. J. Winkels, S. B. Kroonenberg, M. Y. Lychagin, G. Marin, G. V. Rusakov, and N. S. Kasimov, Appl. Geochem., 13, 581-591 (1998).

117. J. K. Cochran, M. Frignani, M. Salamanca, L. G. Bellucci, and S. Guerzoni, Marine Chem., 62, 15-29 (1998).

118. A. C. Ruiz-Fernández, C. Hillaire-Marcel, F. Páez-Osuna, B. Ghaleb, and M. SotoJiménez, Appl. Geochem., 18, 577-588 (2003).

119. H. Yang and N. Rose, Environment Internat., 31, 63-75 (2005).

120. C.-T. A. Chen, J.-K. Wann, and J.-Y. Lou, Chemosphere, 43, 287-294 (2001).

121. K. Loukola-Ruskeeniemi, A. Uutela, M. Tenhola, and T. Paukola, J. Geochem. Explor., 64, 395-407 (1998).

122. W. Shotyk, D. Weiss, J. D. Kramers, R. Frei, A. K. Cheburkin, M. Gloor, and S. Rees, Geochim. Cosmochim. Acta, 65, 2337-2360 (2001).

123. M. A. Vile, R. K. Wieder, and M. Novak, Biogeochem., 45 (1999).

124. D. Weiss, W. Shotyk, J. D. Kramers, and M. Gloor, Atmos. Environ., 33, 3751-3763 (1999).

125. J. M. Benoit, W. F. Fitzgerald, and A. W. H. Damman, Environ. Res. A, 78, 118-133 (1998).

126. P. Pheiffer Madsen, Nature, 293, 127-130 (1981).

127. N. Givelet, F. Roos-Barraclough, and W. Shotyk, J. Environ. Monit., 5, 935-949 (2003).

128. F. Roos-Barraclough and W. Shotyk, Environ. Sci. Technol., 37, 235-244 (2003).

129. M. Krachler, C. Mohl, H. Emons, and W. Shotyk, Environ. Sci. Technol., 37, 26582667 (2003). 
130. B. Holynska, B. Ostachowicz, J. Ostachowicz, L. Samek, P. Wachniew, A. Obidowicz, P. Wobrauschek, C. Streli, and G. Halmetschlager, Sci. Tot. Environ., 218, 239-248 (1998).

131. L. Ukonmaanaho, T. M. Nieminen, N. Rausch, and W. Shotyk, Water, Air, Soil Poll., 158, 277-294 (2004).

132. N. Rausch, T. M. Nieminen, L. Ukonmaanaho, G. Le Roux, M. Krachler, A. K. Cheburkin, G. Bonani, and W. Shotyk, Environ. Sci. Technol., 39, 5989-5998 (2005).

133. N. Rausch, Deposition and Fate of Trace Metals in Finnish Bogs and Implications for the Use of Bogs as Geological Archives, PhD Thesis, University of Heidelberg, Heidelberg, 2005, pp. 1-203.

134. N. Rausch, L. Ukonmaanaho, T. M. Nieminen, M. Krachler, and W. Shotyk, Environ. Sci. Technol., 39, 8207-8213 (2005).

135. G. Le Roux, Fate of Natural and Anthropogenic Particles in Peat Bogs, Ph.D Thesis, University of Heidelberg, Heidelberg, 2005, pp. 1-217.

136. W. Shotyk, M. Krachler, A. Martinez-Cortizas, A. K. Cheburkin, and H. Emons, Earth Planet. Sci. Lett, 199, 21-37 (2002).

137. C. Boutron, U. Görlach, J. P. Candelone, and M. A. Bolshov, Nature, 353, 153-156 (1991).

138. S. Hong, J. P. Candelone, C. C. Patterson, and C. Boutron, Science, 265, 1841-1843 (1994).

139. K. J. R. Rosman, W. Chisholm, S. M. Hong, J. P. Candelone, and C. F. Boutron, Environ. Sci. Technol., 31, 3413-3416 (1997).

140. K. J. R. Rosman, C. Ly, K. Van de Velde, and C. F. Boutron, Earth Planet. Sci. Lett., 176, 413-424 (2000).

141. P. Vallelonga, K. Van de Velde, J. P. Candelone, V. I. Morgan, C. F. Boutron, and K. J. R. Rosman, Earth Planet. Sci. Lett., 204, 291-306 (2002).

142. G. Tao, R. Yamada, Y. Fujikawa, A. Kudo, J. Zheng, D. A. Fisher, and R. M. Koerner, Talanta, 55, 765-772 (2001).

143. H. Marschner, Mineral Nutrition of Higher Plants, Academic Press, Cambridge, 1995, pp. 1-889.

144. R. D. Davis and P. H. T. Beckett, New Phytol., 80, 23-32 (1978).

145. F. C. Lozano and I. K. Morrison, J. Environ Qual., 11, 117-441 (1982).

146. T. M. Nieminen, J. Environ. Monit., 6, 888-896 (2004).

147. D. H. S. Richardson, P. J. Beckett, and E. Nieboer, in Nickel in the Environment (J. A. Nriagu, ed.), John Wiley \& Sons, Toronto, 1980, pp. 367-406.

148. T. M. Nieminen, J. Derome, and A. Saarsalmi, Water, Air, Soil Pollut., 157, 269-279 (2004).

149. R. R. Brooks, in Plants that Hyperaccumulate Heavy Metals. Their Role in Phytoremediation, Microbiology, Archaeology, Mineral Exploration and Phytomining (R. R. Brooks, ed.), CAB International, Wallingford, 1998, pp. $1-14$.

150. T. M. Nieminen, J. Derome, and H.-S. Helmisaari, Environ. Pollut., 106, 129-137 (1999).

151. T. V. Chernenkova and R. G. Kuperman, Water, Air, Soil Pollut., 111, 187-200 (1999). 
152. M. Salemaa, J. Derome, H.-S. Helmisaari, T. Nieminen, and I. Vanha-Majamaa, Sci. Tot. Environ., 324, 141-160 (2004).

153. M. Turunen, S. Huttunen, K. E. Percy, C. K. McLaughlin, and J. Lamppu, New Phytol., 135, 501-515 (1997).

154. J. E. Gawel, C. G. Trick, and F. M. M. Morel, Environ. Sci. Technol., 35, 2108-2113 (2001).

155. B. W. Wood, C. C. Reilly, and A. P. Nyczepir, Hort. Science, 39, 1238-1242 (2004).

156. G. Tyler, Bot. J. Linnean Society, 104, 231-253(1990).

157. H. Raitio, Influence of Sample Washing on the Foliar Chemical Composition, A review for the 3rd Meeting of the Forest Foliar Expert Panel - ICP Forests, Vienna, 1995, pp. 1-8.

158. M. V. Kozlov, E. Haukioja, A. V. Bakhtiarov, D. N. Stroganov, and S. N. Zimina, Environ. Pollut., 107, 413-420 (2000).

159. S. Clemens, M. G. Palmgren, and U. Krämer, Trends Plant Sci., 7, 309-315, (2002).

160. D. A. Cataldo, T. A.Garland, and R. E. Wildung, Plant Physiol., 62, 563-565 (1978).

161. S. Singh, A. M. Kayastha, R. K. Asthana, and S. P. Singh, J. Plant Nutrit., 27, 1543-1560 (1990).

162. J. Molas, Environ. Exp. Bot., 47, 115-126 (2002)

163. D. Mishra and M. Kar, Bot. Review, 40, 395-452 (1974).

164. L. Schreiber, K. Hartmann, M. Skrabs, and J. Zeier, J. Exp. Bot., 50, 1267-1280 (1999).

165. P. J. Jackson, P. J. Unkefer, E. Delhaize, and N. G. Robinson, in Environmental Injury to Plants (F. Katterman ed.), Academic Press, San Diego, 1990, pp. 231255.

166. L. O. Tiffin, Plant Physiol., 48, 273-277, (1971).

167. M. H. Timperley, R. R. Brooks, and P. J. Peterson, J. Exp. Bot., 24, 889-895 (1973).

168. D. A. Cataldo, T. A. Garland, and R. E. Wildung, Plant Physiol., 62, 566-570 (1978).

169. T. Nieminen and H.-S. Helmisaari, Tree Physiol., 16, 825-831 (1996).

170. M. J. McLaughlin, in Bioavailability of Metals in Terrestrial Ecosystems (H. Allen ed.), SETAC Press, Pensacola, FL, 2002, pp. 39-68.

171. S. Sauvé, in Bioavailability of Metals in Terrestrial Ecosystems (H. Allen ed.), SETAC Press, Pensacola, FL, 2002, pp. 7-37.

172. H. Allen, in Bioavailability of Metals in Terrestrial Ecosystems (H. Allen ed.), SETAC Press, Pensacola, FL, 2002, pp. 1-5.

173. I. F. Poulsen and H. C. Bruun Hansen, Water, Air, Soil Pollut., 120, 249-259 (2000).

174. J. D. Wolt, Soil Solution Chemistry: Applications to Environmental Science and Agriculture, John Wiley \& Sons, Inc., New York, 1994, pp. 1-345.

175. J. Derome and T. Nieminen, Environ. Pollut., 103, 219-228 (1998).

176. A. Tessier, P. G. C. Campbell, and M. Bisson, Anal. Chem., 51, 844-851 (1979).

177. U. Föstner, Int. J. Environ. Anal. Chem., 51, 5-23 (1993).

178. F. M. Tack and M. G. Verloo, Sci. Tot. Environ., 178, 29-36 (1996).

179. M. Kaasalainen and M. Yli-Halla, Environ. Pollut., 126, 225-233 (2003). 
180. E. Marguí, V. Salvadó, I. Queralt, and M. Hidalgo, Anal. Chim. Acta, 524, 151-159 (2004).

181. T. M. Nieminen and A. Saarsalmi, Geochem.: Explor. Environ., Anal., 2, 167-174 (2002).

182. J. Derome, A.-J. Lindroos, and K. Niska, Scand. J. For. Res., 13, 421-428 (1998).

183. A.-J. Lindroos, Finnish Forest Research Institute, Research Papers, 679, 1-73 (1998).

184. J. Proctor, J. Ecol., 59, 827-842 (1971).

185. P. Tamminen, in Forest Condition in a Changing Environment-the Finnish Case (E. Mälkönen ed.) Kluwer Academic Publishers, Dordrecht, 2000, pp. 72-86. 
